\title{
Co-production of knowledge among rural women: paths to female recognition in rural areas
}

\author{
Coprodução de conhecimentos entre mulheres rurais: \\ caminhos para o reconhecimento feminino no meio rural
}

\author{
Alessandra Matte \\ Verônica Bogado Camporezi ${ }^{b}$ \\ Talia Callegaro de Jesus ${ }^{c}$
}

Gabriela Litre $^{d}$

Márcia de Fátima de Moraes $^{\mathrm{e}}$

Anderson Brilhador ${ }^{f}$

${ }^{a}$ PhD in Rural Development, Professor, Postgraduate Program in Agroecosystems (PPGSIS), Universidade Tecnológica Federal do Paraná (UTFPR), Santa Helena, PR, Brazil

E-mail: amatte@utfpr.edu.br

${ }^{b}$ Undergraduate Student (Agronomy), Universidade Tecnológica Federal do Paraná (UTFPR), Santa Helena, PR, Brazil E-mail: veronicacamporezi23@hotmail.com

c Undergraduate Student (Agronomy), Universidade Tecnológica Federal do Paraná (UTFPR), Santa Helena, PR, Brazil E-mail: taliacallegaro@hotmail.com

${ }^{d}$ PhD in Geography and Urban Spatial Planning, Full Associate Researcher, Centro de Desenvolvimento Sustentável, Universidade de Brasília (CDS/UnB), and Senior Visiting Researcher, University of Montpellier, France E-mail: gabrielalitre@yahoo.com

${ }^{e}$ Master in History, Researcher, Universidade Federal do Rio Grande do Sul (UFRGS), Porto Alegre, RS, Brazil E-mail: marciamoraesfa@gmail.com

${ }^{f}$ Master in Informatics, Professor, Universidade Tecnológica Federal do Paraná (UTFPR), Santa Helena, PR, Brazil E-mail: brilhador@utfpr.edu.br doi:10.18472/SustDeb.v12n2.2021.37700 


\section{ABSTRACT}

This article explores the potential of dialogue networks as tools for valuing rural women and overcoming the traditional marginalization of rural women in the countryside. The guiding hypothesis is that when given opportunities to co-produce solutions in a participatory manner and an enabling environment, women can articulate and express their challenges and visualize desirable futures. The results confirm this hypothesis to the extent that women experience and execute these premises in the established spaces of dialogue. The recommendations are for the promotion of actions and policies that provide environments in which women can reframe their role in society and the family.

Keywords: Autonomy. Empowerment. Inclusion. Stakeholders. Productive value.

\section{RESUMO}

Este artigo explora o potencial das redes de diálogo como ferramentas de valorização das mulheres rurais e de superação da tradicional marginalização destas no campo. A hipótese norteadora é a de que, quando dadas as oportunidades de coproduzir soluções de maneira participativa e em um ambiente propício, as mulheres conseguem articular e expressar seus desafios e visualizar futuros desejáveis. Os resultados confirmam essa hipótese na medida em que as mulheres vivenciam e executam essas premissas nos espaços de diálogo estabelecidos. As recomendações são para o fomento de ações e políticas que propiciem ambientes em que mulheres possam ressignificar seu papel na sociedade e no núcleo familiar.

Palavras-chave: Autonomia. Empoderamento. Inclusão. Agentes de desenvolvimento. Valor produtivo.

\section{INTRODUCTION}

The place that women occupy in the productive systems of different rural establishments is commonly less valued than those of men, which is a reality that is accentuated among the social category of family farmers in Brazil (AMORIM; FIÚZA; PINTO, 2015; BUTTO et al., 2014; COSTA; BEVILAQUA, 2018; SPANEVELLO et al., 2021). This scenario is especially guided by cultural conventions of hierarchy and power relations, thereby positioning women in a type of shadow of the partner. In different global contexts, it is recognized that women's performance in the field is fundamental for the maintenance of productive family systems; however, depending on the sociocultural relations of which they belong, they are little valued or recognized in their decision-making potential, as found, for example, in Uruguay (COURDIN; LITRE; CORREA, 2014; LITRE, 2015), Mexico (CAVALLOTTI VÁZQUEZ et al., 2013; LISBOA; LUSA, 2010) and Brazil (HERRERA, 2019; MORAES, 2020; SPANEVELLO; MATTE; BOSCARDIN, 2016; SPANEVELLO et al., 2021). In particular, rural women are herein understood as those who have their lives intertwined with the rural environment's productive, reproductive, and sociocultural aspects; they are also identified in the literature as women farmers or rural women (SALES, 2007).

According to the Food and Agriculture Organization of the United Nations (FAO/UN), in general, rural women work more than men, since, in addition to their paid work as producers or family farmers, they are usually in charge of the education, care, and feeding of their children and often of elderly family members or others in a situation of dependence (UN, 2019). On the other hand, despite this image of invisibility in production, the reality, even if not always recognized by the patriarchal system, is that women play a central role in the development of family nuclei, productive activities, and rural communities since they act in these spaces and play roles in the aggregation and organization of rural activities (SILVA et al., 2015; SPANEVELLO et al., 2021).

Therefore, actions that encompass the gender issue, especially in the rural context, and in activities directly related to food production, figure as a contribution to achieving the Sustainable Development Goals (SDGs), especially the fifth, i.e., "Achieve gender equality and empower all women and girls". Thus, the challenge of a successful workshop' strategy with this public makes it possible to provide conditions to these women and to their family and community surroundings to realize the importance of their participation in the decisions and actions of the family group. By expressing their experiences 
and having their voices heard, these women allow the empowerment process to develop from their reflections: from how they perceive and understand the world they are a part of and how they understand their importance and value in the rural sphere.

Currently, at least a part of this female population is already being instructed to invest in their education and assume new positions and functions within the family production (FAGUNDES; SPANEVELLO; MATTE, 2021; HORA; NOBRE; BUTTO, 2021). Although these occasional trends seem encouraging, we are far from eliminating the scenario of masculinization of the countryside and the social invisibility of women, which is the dominant pattern for many women in rural areas. Thus, two conceptual bases contribute to the analysis of rural women's work in their communities and family nuclei, namely, the distinction between reproductive and productive spaces and the conception of the co-production of knowledge. Rural women' work is commonly treated as having a "reproductive" value which refers to its function of guaranteeing basic conditions for the family to function, such as ensuring that the family eats for its members to continue working, seeing that clothes are sewn, washed and ironed so that the family can be dressed, making sure that the house is clean, preserving health and ensuring that other members of the family can continue producing, among others.

According to Herrera (2017, p. 2), this means that domestic work has its value related to the capitalist mode of production, which implies "being considered unproductive, given that the product resulting from this laborious effort does not constitute exchange value but rather use-value." For example, in a study about women in family agroindustries in Santa Catarina, Boni (2005) points out that when the product resulting from the work commonly performed by women, such as the processing of food (jam, bread, sweets, cheese), is sold, it migrates to the productive field, while the woman, the subject of production, remains in the reproductive field.

Productive work, in turn, comprises spaces in which women act in activities aimed at exchanging the product generated for monetary value, a scenario in which rural women are often seen as "helpers" (HERRERA, 2017; SPECHT, 2019). That is, productive space or value is about paid work, while reproductive space is understood in the social imaginary ${ }^{2}$ as "without monetary value." The resignification of this conception is one of the ways to transform the invisibility of rural women into autonomous agents, insofar as it allows recognizing their role in the prevailing social systems and acknowledging the productive value of rural women's work, which is often nonmonetized. According to Specht (2019), this allocation of women to a reproductive space becomes an obstacle to their productive organization and restricts their participation in different markets so that such issues directly influence the processes of building empowerment conditions. In line with this understanding, the concept of co-production represents a path for this process of change.

Initially coined in the 1980s by the Indian researcher Sheila Jasanoff, the concept of co-production is used to address the production of knowledge within the field of social studies of science (PIMENTA, 2020). The researcher understands that science and society mutually constitute each other, which leads to analyses that "encompass the political, cultural, and legal dimensions of science" (PIMENTA, 2020, p. 51). Jasanoff (2007, p. 33) clarifies that "science fixes our attention on the knowable, leading to an overreliance on fact-finding. Even as scientists recognize the limits of their investigations [...]". The author's international research allows her to assert that disciplined methods are needed to accommodate the partiality of scientific knowledge, calling for "universities to teach modes of knowing that are often left aside in the expansion of scientific understanding and technological capacity" (JASANOFF, 2007, p. 33).

Since Jasanoff's $(1990,2007)$ contributions, the concept of knowledge co-production has been used as a tool to foster the bringing together of research and practice, the sharing of collective experiences, and the valuing of trajectories and knowledge (BARCELLOS, 2020; MOLNÁR et al., 2020; POHL et al., 2010). For Armitage et al. (2011, p. 1001), knowledge co-production consists of a "collaborative process of bringing together a plurality of sources and types of knowledge to address a defined problem and build an integrated understanding." Therefore, a knowledge co-production space comprises the conjunction of local, tacit, and traditional knowledge with science. In such a way, developing knowledge co-production 
processes embraces establishing trust networks among those involved to establish more informed decision-making (FILIPE, et al., 2017; HARVEY; COCHRANE; VAN EPP, 2019; MOLNÁR et al., 2020). In this sense, Lindoso et al. (2020) point out that the use of the concept of co-production of knowledge, when oriented to the solution of local problems with a focus on local actors (in our case, rural women), allows positive results by promoting technical and reflective autonomy of the participating actors.

Accordingly, this study combines the concepts of productive recognition and co-production of knowledge to reflect and promote the autonomy of rural women. Therefore, we seek to understand how the processes of co-production of knowledge translate into specific products or results in applied research through extension actions.

For the more equitable participation of rural women and families in general, access to information through dialogue networks, which generates trust and favours the co-creation of solutions, shows itself as a key to encouraging the permanence of this public in rural areas. Employing participant observation, the current research aims to analyze, from the performance of rural women, the process of co-production of knowledge for the productive valorization of this social category.

\section{MATERIALS AND METHODS}

The present study is the result of participant observation through the development of an extension project that has the co-production of knowledge as its guiding principle since the researchers became involved in the work in a cooperative way based on a collective process of self-reflection. According to Hernández Sampieri et al. (2000, p. 419), observation is not mere contemplation; it implies entering deeply into social situations and maintaining an active role, as well as "permanent reflection, paying attention to details, events, events and interactions". For the authors, observation is an important research mechanism to generate hypotheses for future studies. In particular, reflections should occur during the research process for it to be participatory and not only afterwards, as in traditional research.

Based on this understanding, the activities of the extension project took place in the municipality of Santa Helena in western Paraná state, Brazil (Figure 1). The group of actors involved in the activity consisted of one teacher and two students from the Universidade Tecnológica Federal do Paraná (UTFPR) linked to the Agronomy program, two representatives from the Centro de Referência de Assistência Social (Cras) of the municipality, and a group of rural women with a history of being assisted by Cras. The choice of a preexisting group for action is based on the intention of collaborating with processes of autonomy and combatting the vulnerable situations in which these women find themselves through learning processes, in addition to justifying the importance of this action, insofar as it is a real problem that local society has demanded be addressed with specific actions

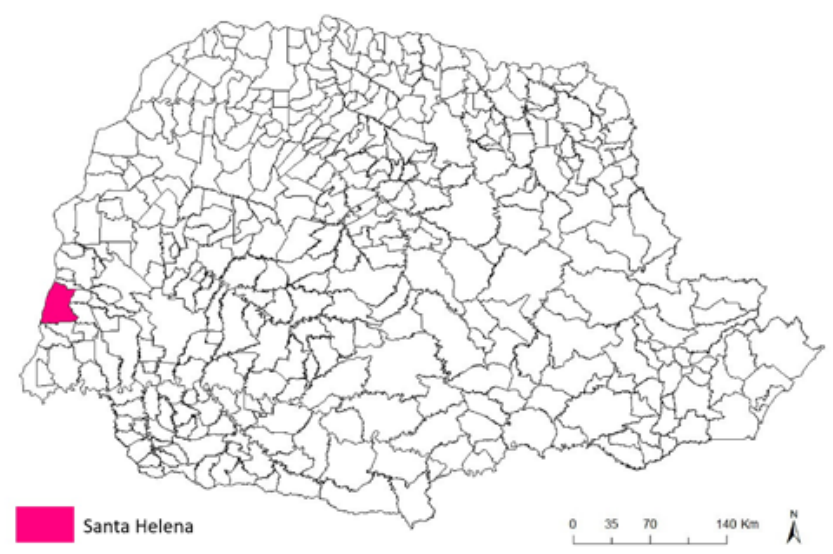

Figure 1 | Location of the municipality of Santa Helena in western Paraná Source: Authors. 
The learning process can occur individually or in groups. According to Armitage et al. (2011), a focus only on the individual neglects the social and institutional context in which learning occurs. According to Pohl et al. (2010), there are two forms of knowledge co-production: the mediated and the now. The first occurs through mediation to facilitate dialogue and shared understandings between academic and non-academic actors. The second, which is of interest to us and guiding our research, comprises collaborative efforts to confront "each other's worldviews in a purposefully open social and intellectual space" (POHL et al., 2010, p. 276). In particular, in this second process, participants are deliberately "called upon to deal with the social and cognitive challenges of accommodating contrasting worldviews" (HARVEY; COCHRANE; VAN EPP, 2019, p. 112).

Two workshops were conducted with the rural women's group, which comprised six women, one man (a husband of one of the members), and one child (a granddaughter of one of the members). For the workshops, the other members of the families were invited, which explains the presence of the man and child. The age range of the adult participants was 42 to 68 years old. The purpose was to trigger reflections by the women about their realities through the exchanges, since listening to the stories of others is a way to rethink one's own life. This methodological choice sought to encourage intergender dialogue, which allowed learning during training to be more easily socialized within the family and the community through participatory methods.

In summary, two workshops were held with rural women in a space made available by the municipal school, where a women's group had already been holding meetings for the development of other activities. The first workshop consisted of the initial approach, in which the team introduced itself, explained the purpose of the meetings and invited the women and their families to participate, with their consent and acceptance. On this occasion, the women were consulted about providing authorization to use and disclose the information constructed during the workshops and their consent was documented.

All the women who already participated in activities promoted by Cras were married and had children. Among them, we received information that at least two suffered sexual abuse during their childhood and adolescence, and to some extent, all had previously presented reports and testimonies of psychological violence within the family.

These women identify themselves as housewives, perform productive activities on the properties, often define themselves as "helpers" of their partners, but assume the responsibility for the education and care of the children, the domestic environment of the family with clothes, food, and hygiene, and care for small gardens and the raising of some animals. Their income comes from federal government assistance for those with school-age children and revenue generated by their husbands from the sale of products or services. None of the women market specific products.

The second workshop had three moments. The first featured a poster with the question "What makes you happy?" Everyone present participated in the dialogue while the students recorded the discussion on the poster. For each repetition of a motivating aspect of happiness, an asterisk was incorporated into the poster. During and after the creation of the poster, it was possible to identify similarities within the group, which allowed us to build an amalgam of affinities.

The second moment consisted of the process of identifying the value given to the women's productive work, listing all the activities they carried out and then assigning a monetary value ${ }^{3}$ for the women to reflect on the value of the work performed but hidden in the family nuclei by paid work.

The third moment consisted of a World Café exercise, which is a dialogue facilitation technique developed in 1995 by Juanita Brown and David Isaacs. This tool enables groups to access collaborative intelligence, which becomes increasingly powerful as exchanges of places and knowledge take place (BROWN; ISAACS, 2007; FERNANDES, 2015). The four assumptions that guide the World Café, which is presented and established at the beginning of the activities, are as follows: 1) no one is equal to anyone; 2 ) no one is better than anyone else; 3 ) no one owns the truth, and 4) everyone has something 
to contribute. Facilitation techniques can be a way to engage people in difficult conversations about complex issues. This technique contributed effectively to achieving the desired workshop objectives.

Esquivel Gámez et al. (2014) point out that although the technique is particularly recommended for larger groups of people, its application in small groups also leads to good results, generating a pleasant environment and promoting collaborative work. To promote a space for the co-production of knowledge, the participants were divided into two groups. Each was provided with coloured pens and crayons so that they could draw on a poster given to each group, containing the following question: "What was it like to be young, a woman and a man, in the time of your grandparents?" The choice of drawing instead of writing was because some of the participants do not know how to write or can only write their names.

The richness of co-production was found mainly in the process of creating the drawings, a moment when there was dialogue and reflection on what was expressed in answer to the question. The subsequent dialogue allowed for the maturation of ideas, especially by contrasting the present with the desired future.

The students acted as facilitators, encouraging and motivating the participation of all members during the process. Because it was a small group, after the conclusion of the activity, a round of presentations and dialogue about the answers to the guiding question was held.

The main results achieved were drawn from the dialogues conducted during the activities and the presentations of the drawings described and analyzed below. For this analysis, the content analysis technique was used (CRESWELL, 2014). During the production of drawings and presentations, all participants presented their symbologies and the stories behind each image, which allowed them to collectively reflect on the past, present and what they want for the future.

\section{RESULTS AND DISCUSSIONS}

In the southern Brazilian state of Paraná, the female presence in rural areas has drastically decreased since the 1980s, when more than 1,507,424 women were recorded residing in rural areas, which was then equivalent to $19.76 \%$ of the rural population (IBGE, 2011). For the municipality of Santa Helena, on the western coast of the state, $38.14 \%$ of the population was female during the same period. The rural exodus, especially by women and young people, led to a drastic reduction in the female presence; in 2010, women accounted for only $6.96 \%$ of the state's population and $22.8 \%$ of the population of the municipality of Santa Helena (IBGE, 2011). The absence of more up-to-date data and the existence of specific groups to assist women in this region was a particular motivation for carrying out the extension project.

The results achieved thus far can be understood from two aspects: the co-participating team and the public involved. Regarding the executing team, participating in the reading and dialogue spaces before the workshops provided an opportunity for the students who had been working on the project to mature. This is a crucial outcome, with implications in the professional profile of these young students. By sharing experiences and trajectories, their way of seeing the individual has been transformed, thereby enabling them to have a more human understanding of the professional issues that they will find in the labour market. In this regard, Esquivel Gámez et al. (2014, p. 414), in applying the World Café technique in study programs in the area of information technology (IT), conclude that the articulation of the two worlds studied - the university and the business world - "is vital for the improvement of the graduate's competencies." Involvement in this exercise will certainly increase the possibilities of creating conditions for the development of the future professional.

Regarding the participating public, the special interest of women in the workshops can be seen by the prompt positive response to participate when the invitation was made, with a special interest in the invitation to participate also being extended to their partners and people with whom they share a home. Despite the low involvement of their partners, the women participated enthusiastically in the activity by sharing their stories and experiences. 
In the following workshop, it was possible to understand that this desire for the participation of other family members implied that there was a need for space to speak, even if the speaking is through drawings and not through verbalization. Verbalizing is a work in progress for some of the women participating in the workshop, either because of their fear of the listener reaction or because of the uncertainty regarding the consequences of their speech. In the workshop with the participation of families, it was possible to confront, respectfully and constructively, the contrasts of the answers, particularly between the male/husband participant and the women. It is important to note that the absence of the other partners can at first be understood from the perspective of work, as they cannot abandon the activities performed on the property. However, when we reflect on their absence from the perspective of gender relations, defined conceptually by Scott (1991), it is possible to conclude that women, at least in the community studied, are more likely to reflect on their lives than are men.

The social structure also impacts these men, given that during the workshop, it is necessary to talk about oneself, including sharing memories of childhood and community life. That is, showing feelings or some degree of vulnerability in public does not match the precepts of masculinity expected of rural men (CONNEL, 2018; VIVEROS VIGOYA, 2018). The first activity of the workshop, which consisted of a dialogue on "What makes you happy," enabled the assembled group, students, Cras agents, women, and one man to identify the similarities and shared values (Figure 2). The preponderance of family ties as a mechanism of social recognition and the importance of work for the feeling of inclusion and belonging emerged as the main values pointed out by the participants. In the case of women in particular, beyond economic factors, work characterizes and promotes their identities as rural women and subjects in the productive structure. In this sense, work is a value transmitted from generation to generation. From an early age, with the family understood as the primary responsibility in this process of learning the trades and values that will follow them throughout life, women have learned about animal care, domestic work, agricultural activities, etc. (MORAES, 2020).

Among the shared conceptions, a relevant aspect concerns the image of what these women understand as leisure. In contrast to the answers of the students, the Cras agents, the man, and rural women envision leisure as activities in which they can leave home since the "home" is also a workspace. Therefore, being at home is synonymous with work. The women identified this difference by understanding that those who work outside the home want to stay at home when they have the opportunity, especially as leisure. Therefore, when we return to the issue of the absence of partners of most of the workshop participants, this understanding corroborates the understanding of why there is greater availability of women to participate in activities such as these. Due to commercial activities, men tend to circulate more in the public sphere, whereas there is a tendency for women to be conditioned to the private sphere, which in the rural case would be the family property and the domestic space (SPANEVELLO; MATTE; BOSCARDIN, 2016; SPANEVELLO et al., 2021). To this end, encounters such as these make it possible for women to take a break from the daily reality of domestic work and farming.

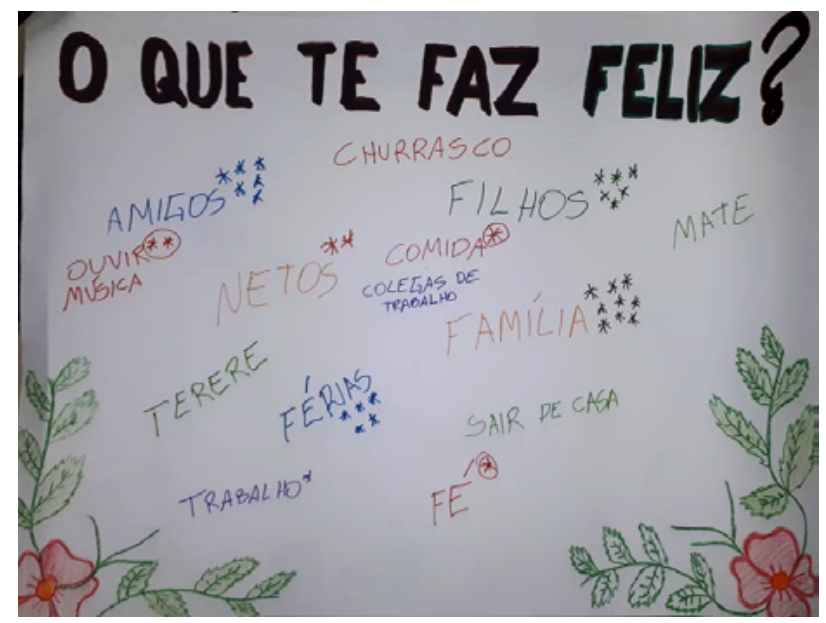

Figure 2 | Dynamics of group connection Source: Authors' record during the extension activities. 
Thus, the dynamics resulted in a change of attitude of the women participants during the workshop itself, in the sense of feeling valued by identifying, on their own, and with the presence of other family members, the value of their work. In a review on the value of productive and reproductive work, Herrera (2017) points out that reversing this situation involves formal and informal institutional arrangements that serve the reproductive spaces occupied by rural women, such as daycare centres, schools, and hospitals. Therefore, by privileging the mercantile production of goods and services, material and immaterial activities "aimed at people's emotional well-being, particularly family domestic work" are made invisible, thus reinforcing the need to reinterpret the understanding of domestic work (MELO; CASTILHO, 2009, p. 154).

In this regard, data from the National Continuous Household Sample Survey, PNADc (IBGE, 2018), point out that $92.2 \%$ of women perform household chores. The average number of hours devoted to housework and/or caring for people is 23.8 hours per week for women and 12 hours for men (IBGE, 2018). Continuing with the activities, the results of the third exercise are illustrated in Figure 3.
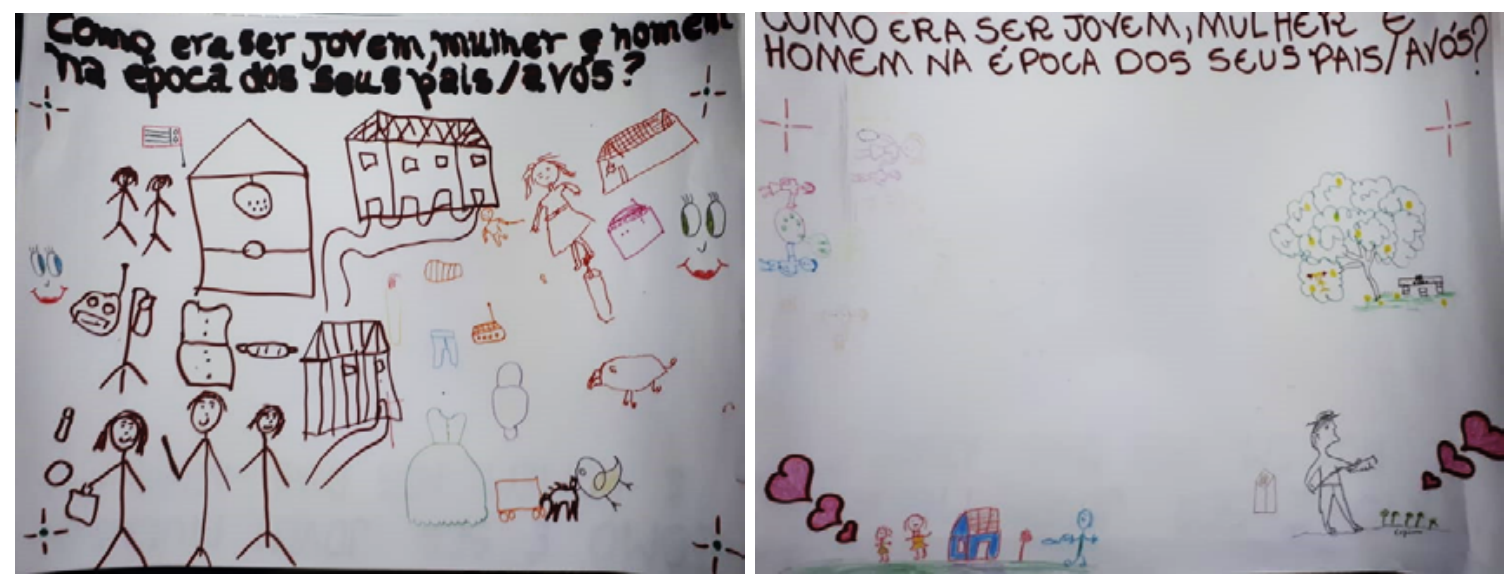

Figure 3 | Results of the deconstruction workshop on "What was it like to be young, female, and male in your parents'/grandparents' time?"

Source: Authors' record during extension activities

In the drawings, the women present images that refer to a childhood close to animals, animal husbandry, and domestic learning (such as making bread and cooking). They also illustrate spaces that were reminiscent of joy, such as the remains of a tree, eating fruit, and playing with animals and plants.

The results for many women show, in general, a childhood that is marked by physical and psychological violence. The effects of these experiences show in their current personality, according to them, in particular through fear and silence. This is confirmed by the drawings that show fathers with instruments of aggression, as in the lower corner of the second image where the image of a doll represents a man with a "soiteira" (an instrument made with a braided bovine leather strap, tied to a piece of wood, used mainly to handle cattle). In the lower corner of the first image, there is an image of three figures representing people, the second of which is a man with a "stick" to punish and "educate", according to the woman who drew the picture.

Regarding violence against women, data presented in the second State Plan for Women's Rights 20182021 of Paraná point to a generalized increase in violence against women, in which the homicide rate of women grew between 2001 and 2015 to 26.61 deaths per 100,000 inhabitants (SANTOS; REZENDE; MARTINS, 2018). Additionally, according to the authors, the main type of violence recorded is physical violence, as represented by $39.33 \%$ of the records, followed by psychological and moral violence, as with $24.29 \%$ of the cases. Therefore, this extension project responds to local demand but also a global one, insofar as the theme of violence emerges as a result of childhood but also allows us to discuss it currently and in the presence of other family members, as well as among the women themselves. 
It is important to understand that the women participating in the workshop have been made invisible as the fruit of a society anchored in logic guided by patriarchy; that is, a form of social and family organization in which the man, the patriarch, submits the other members of the family to his power (COLLING; TEDESCHI, 2019) This power system comprises a series of norms that end up negotiating relationships that are imposed on society as a whole and especially within family nuclei (AGUIAR, 2000). The patriarchal logic remains firmly established in Brazilian life and politics: "the position of women, in the family and society in general, since colonization until today, shows that the patriarchal family was one of the matrixes of our current social organization" (NARVAZ; KOLLER, 2006, p. 1).

However, it is fundamental to understand how gender-based power asymmetries are reproduced, which assigns women to situations of vulnerability and hides their value. What the results indicate are trajectories of oppression allied to marriages that reproduce previous family experiences. The existence of this group of women and the actions of Cras (which is a social assistance centre) point to the creation of local measures to combat this devaluation. Even so, the professionals report the challenge of having a small team to meet the needs of such close monitoring, especially because of the frequent reports of violence. The women see the group as a space of shelter and safety. However, it shows the lack of actions aimed at building autonomy through the integration of the family and society itself. This does not cancel out or hide the creation of credit policies, such as Pronaf Mulher (SILVA et al., 2015; SPANEVELLO et al., 2021), and social assistance policies, such as Bolsa Família, which have been effective at changing this situation in different contexts within Brazil (COUTO, 2020; FRIZZO, 2017; WILLIAMS, 2014). In the case of the women's group, which was the focus of this extension action, Bolsa Família represents the main policy accessed and provides important support for these women.

In line with this, in the drawings, we find symbols associated with domestic work, particularly in that there are few activities that associate childhood with playing. This may be related to the fact that entry into the labour force in rural areas takes place very young and usually occurs between eight and ten years of age (HEREDITA; GARCIA; GARCIA Jr., 1984). Childhood for females is associated with the burden of developing activities related to domestic chores, such as caring for the house and younger siblings, from an early age. In contrast, the look back on childhood for the only male participant consisted of games such as hunting and fishing, which are activities unrelated to housework or memories of violence.

Undoubtedly, the space of co-production of knowledge, through the exchange of experiences during the workshops, allowed those involved to revisit their life stories, which often ended up awakening nostalgic memories of the past. At other times, they were associated with painful, and sometimes traumatic, memories, which, when shared, could be processed and resignified. In this sense, among the women, it was observed that the aspects that emerged from the workshops were related to hard work, the lack of opportunity and space to speak, and the "arranged", often abusive, relationships. For women, their childhood experiences significantly influence how they act today as mothers and grandmothers. For them, attitudes that offer security and freedom of choice so that their daughters/ granddaughters can choose their relationships and make their professional decisions are measures to protect them from going through similar situations that have oppressed them.

On the other hand, the male participating in the activity had little sympathy for these elements and considered that the current situation is worrisome since it indicates that men have "lost control" over some aspects of social relationships. For him, social control, even if by oppression, was absent from the current social dynamics. For women, this means freedom of choice and autonomy, whereas, for men, it means loss of power. The interesting thing about the female presence is that, contrary to what one might imagine, the man did not inhibit the women's participation; on the contrary, he showed himself to be more inhibited, while they felt the liberty to speak in their space. Nevertheless, it did not prevent him from expressing his understanding that there was more "control" a few decades ago. This result was important, as the women argued their point of view, especially about the lack of freedom for deciding about assets and professional choice. 
In the workshops, gender markers are punctuated in the reflections of those involved so that women tend to resignify a past life marked by work that entailed the absence of autonomy and valorization, while men tend to assimilate the loss of male hegemony. Perceiving these gender relations in the discourse of men and women makes it possible to identify precursor elements of the situation of women in rural contexts, as well as to create alternatives aimed at promoting gender equality, in which both female and male subjects perceive their importance in the social structure, not viewing it as a threat to historically established power relations.

Hooks (2020, p. 30) states that "feminist awareness for men is as essential to the movement", as it is for women's groups, such that without the male presence as an ally in the struggle, the movement tends not to progress. In particular, it is necessary to understand the power relations that guide the internal dynamics of families, as well as of the rural communities in which they are inserted. That is if gender vulnerability is not natural but rather socially and culturally constructed, then resignifying this relationship is a possible path (SALES, 2007; SOARES, 2017). Thus, the results allow us to see that women's autonomy is still recent in Brazilian society and needs to make important advances, especially regarding the participation of other social actors and greater investments of public policies that aim to promote gender equality in rural areas, so as not to reduce these issues to just a women's struggle.

The results allow us to explain that "empowering" women are not necessarily synonymous with fixing women and girls in the countryside. As Freire (1987) said, it is fundamental to generate conditions so that they can choose freely and in an informed way what they want to do to live with dignity (in the countryside or the city). Thus, empowering includes processes that allow women to live the life they desire, without boundaries imposed by gender and patriarchal oppression, as reflected by Sardenberg (2006). This change, although gradual, is taking place, as the data from the Agricultural Census show. In 2006, there were seven establishments run by women who have completed their higher education in the municipality of Santa Helena (IBGE, 2006). In 2017, this number doubled, and there are currently 14 women running agricultural establishments who have completed their higher education (IBGE, 2019). This reality is also found in the scenario of the Brazilian territory, starting with the number of farming establishments run by women, which accounted for 656,255 in 2006 and currently total 946,075 , which is an increase of $31 \%$ for the period (IBGE, 2006, 2019).

Such results are in line with the analysis and projection that the participants present when analyzing adults' lives in the past, the current reality, and the future projection, especially for children and grandchildren. After all the activities were carried out, at the end of the meeting the women presented a different posture, with shared understandings about the need for their daughters to study and be able to choose their destiny within the available conditions since the rules of the past that guided their future did so with more flexibility than what was experienced by their mothers and grandmothers.

\section{CONCLUSIONS}

The guiding hypothesis of the participant observation resulting from the research project is that when given the opportunities to co-construct or co-produce solutions in a participatory manner and an enabling environment, historically marginalized women in the countryside can articulate and express their challenges and envision desirable futures, including pathways to achieve that future in a free and informed manner. The results allow us to confirm this hypothesis, as women experience and execute these premises in the established spaces for dialogue.

The use of participatory methodologies to establish a space for the co-production of knowledge has cultivated important seeds that foster reflections in the family nuclei and, especially, in rural women about their protagonism and importance. Breaking with beliefs and sociocultural patterns is challenging, and our challenge is to encourage new ways of looking at female protagonism in the rural context. 
Although the central concern throughout this discussion is to explore the potential of dialogue networks as a tool to overcome the marginalized place occupied by women in the rural structure, it is important to clarify that social and gender relations are not static and hierarchical in these rural contexts, since they change according to social and cultural aspects. Notably, the patriarchal structure rooted in the rural environment results in women being subjected to issues such as the invisibility of their labour, the lack of decision-making ability, and low access to education and even marriage. Nevertheless, it would be wrong for the analyses to be limited to the oppressed and oppressors. Therefore, the recommendations are for the promotion of actions and policies that provide spaces for women to resignify, through the co-production of knowledge, their role in society and the family nucleus. Moreover, the need for this dialogue to occur, including with men who, due to the historical structures that guide them, encourage women to remain in situations in which their productive and reproductive value remains invisible.

The extension actions in universities have enabled the recognition of the UTFPR in actions that aim to act on real problems, thereby demonstrating that the professional agronomist who works in participatory extension actions is differentiated in that he has a holistic view of the rural areas by recognizing the importance of sociocultural aspects and productive social categories that are commonly marginalized and made invisible.

\section{ACKNOWLEDGEMENTS}

We would like to thank the Social Assistance Reference Center (Cras) of Santa Helena/PR, in particular social workers Andreia Henrichs and Nágila Goeller, and the UTFPR for the scholarship granted. Special thanks to the rural women and their families, who agreed to participate in the workshops and share their stories with us.

This work was supported by INCT/Odisseia-Observatory of socioenvironmental dynamics: sustainability and adaptation to climate, environmental and demographic changes under the National Institutes of Science and Technology Program (Call INCT - MCTI/CNPq/Capes/FAPs n.16/2014), with financial support from Coordination for the Improvement of Higher Education Personnel (Capes): Grant 23038.000776/2017-54; National Council for Scientific and Technological Development (CNPq): Grant 465483/2014-3; Research Support Foundation of the Federal District (FAP-DF): Grant 193.001.264/2017.

\section{NOTES}

\footnotetext{
${ }^{1}$ In particular, the idea of carrying out the extension project that culminated in the participant observation of this research is the result of local need, given the existence of groups of rural women being assisted by organizations prepared for psychosocial support, combined with the interest of students and teachers involved in the action.

\begin{abstract}
${ }^{2}$ Cornelius Castoriadis coined the concept of social imaginary, commonly used to express social representations rooted in the institutions that guide societies. For more information, see Rodrigues (1998).

${ }^{3}$ The activity involved calculating the financial value of rural women's work through a survey of all the activities performed by them, among which were listed: preparing meals, cleaning the house, washing and ironing clothes, taking care of children/ grandchildren, taking care of the garden and small animals, etc. After listing all the activities they perform, an estimated value was assigned that would be paid to a person who would perform the corresponding activity using as a hypothesis the absence
\end{abstract} of the woman, arriving at an estimate of the monetary value of domestic work, commonly invisible in family nuclei.
}

\section{REFERENCES}

AGUIAR, N. Patriarcado, sociedade e patrimonialismo. Soc. Estado, v. 15, n. 2, Dez. 2000.

ARMITAGE, D. et al. Co-management and the co-production of knowledge: learning to adapt in Canada's Arctic. Global Environmental Change, v. 21, n. 3, p. 995-1004, August. DOI: 10.1016/j.gloenvcha.2011.04.006 
BARCELLOS, V. G. Coprodução, conhecimento e o comum. Tese (Doutorado em Comunicação). Programa de PósGraduação em Ciência da Informação, Universidade Federal do Rio de Janeiro, Rio de Janeiro, 2020.

BONI, V. Produtivo ou reprodutivo: o trabalho das mulheres nas agroindústrias familiares - um estudo na região oeste de Santa Catarina. 2005. Dissertação (Mestrado em Sociologia Política) - Universidade Federal de Santa Catarina. Centro de Filosofia e Ciências Humanas. Programa de Pós-Graduação em Sociologia Política, Florianópolis, 2005.

BROWN, J.; ISAACS, D. O World Café: dando forma ao nosso futuro por meio de conversações significativas e estratégicas. São Paulo: Cultrix, 2007.

BRUMER, A. Gênero e agricultura: a situação da mulher na agricultura no Rio Grande do Sul. Revista Estudos Feministas, Florianópolis, v. 12, n. 1, 2004, p. 205-227.

CAMARANO, A. A.; ABRAMOVAY, R. Êxodo rural, envelhecimento e masculinização no Brasil: panorama dos últimos 50 anos. Revista Brasileira de Estudos de População, Rio de Janeiro, v. 15, n. 2, p. 45-66, jul./dez. 1998.

COlling, A. M.; TedeSCHI, L. A. Patriarcado. In: COlLING, A. M.; TEDESCHI, L. A. Dicionário crítico de gênero. 2. ed. Dourados, MS: Editora da Universidade Federal da Grande Dourados, 2019.

CONNELL, R. Prefácio. In: VIVEROS VIGOYA, M. As cores da masculinidade: experiências interseccionais e práticas de poder na nossa América. Tradutor Allyson de Andrade Perez. Rio de Janeiro: Papéis Selvagens, 2018.

COURDIN, V.; LITRE, G.; CORREA, P. Desarrollo sostenible y transformaciones en la organización del trabajo femenino rural: el caso de las mujeres ganaderas del Uruguay. Sustentabilidade em Debate, v. 5, n. 2, p. 55-75, 2014. DOI: 10.18472/SustDeb.v5n2.2014.10714

COUTO, M. C. A. Empoderamento feminino e políticas de transferência condicional de renda: uma avaliação do Programa Bolsa Família. 2020. Dissertação (Mestrado em Economia) - Universidade Federal de Uberlândia, Programa de Pós-Graduação em Economia, Uberlândia, 2020.

CRESWELL, J. N. Investigação qualitativa e projeto de pesquisa. 3. ed. Porto Alegre: Penso, 2014.

DEERE, C. D. Os direitos da mulher à terra e os movimentos sociais rurais na reforma agrária. Revista Estudos Feministas, v. 12, n. 1, p. 175-204, 2004.

ESQUIVEL GÁMEZ, I. et al. Aplicación de la dinámica grupal Café Mundial, a la actualización de un programa de estudios del área de TI. Academia Journals, San Antonio, Texas, v. 6, n. 4., p. 409-414, sep. 2014.

FAGUNDES, C. C.; SPANEVELLO, R. M.; MATTE, A. Mulheres rurais e as contribuições do uso do crédito rural. In: A Contabilidade como instrumento de gestão. Ponta Grossa/PR: AYA Editora, 2021, p. 91-107.

FERNANDES, M. E. S. A. C. O World Café e o aprendizado pelo diálogo. Tese (Doutorado em Educação) - Faculdade de Educação, Universidade de São Paulo, 2015.

FREIRE, P. Pedagogia do Oprimido. 17 ed. Rio de Janeiro: Paz e Terra, 1987.

FRIZZO, D. O impacto do Programa Bolsa Família na vida de mulheres beneficiárias. 2017. Dissertação (Mestrado em Direito) - Universidade de Passo Fundo, Programa de Pós-Graduação em Direito, Passo Fundo/RS, 2017.

HARVEY, B.; COCHRANE, L.; VAN EPP, M. Charting knowledge co-production pathways in climate and development. Environmental Policy and Governance, London, v. 29, n. 2, p. 107-117, mar/abr. 2019.

HEREDIA, B.; GARCIA, M. F.; GARCIA JÚNIOR, A. O lugar da mulher em unidades domésticas camponesas. In: AGUIAR, N. Mulheres na força de trabalho na América Latina. Petrópolis: Vozes, 1984. 
HERRERA, K. M. Repensando o valor social do trabalho das mulheres rurais. In: SEMINÁRIO INTERNACIONAL FAZENDO GÊNERO, 11., 2017, Florianópolis, Anais [...] Florianópolis: Mundos de Mulheres, 2017.

HORA, K.; NOBRE, M.; BUTTO, A. As mulheres no Censo Agropecuário 2017. Associação Brasileira de Reforma Agrária (Abra): Friedrich Ebert Stiftung, 2021.

INSTITUTO BRASILEIRO DE GEOGRAFIA E ESTATístICA. 2011. Censo Populacional, 2010. Bancos de Dados, Sidra, Tabela 200. Brasília: IBGE, 2011.

INSTITUTO BRASILEIRO DE GEOGRAFIA E ESTATÍsTICA. Censo Agropecuário 2006. Sidra, Tabela 767. Rio de Janeiro: IBGE, 2006.

INSTITUTO BRASILEIRO DE GEOGRAFIA E ESTATístICA. Censo Agropecuário 2017. Sidra, Tabela 6756. Rio de Janeiro: IBGE, 2019.

INSTITUTO BRASILEIRO DE GEOGRAFIA E ESTATÍstICA. Pesquisa Nacional por Amostra de Domicílios Contínua (PNADc). Outras formas de trabalho 2018. Rio de Janeiro: IBGE. 16p. 2018. Available in: https://biblioteca.ibge. gov.br/visualizacao/livros/liv101650_informativo.pdf. Acessed: 20 Feb 2021

JASANOFF, S. Science and public reason. Londres: Routledge, 2012.

JASANOFF, S. Technologies of humility. Nature, v. 450, p. 33, 2007. DOI: 10.1038/450033a

JASANOFF, S. The Fifth Branch: science advisers as policymakers. Cambridge: Harvard University Press, 1990.

LINDOSO, D. P. et al. Uma Odisseia no campo socioambiental da pesquisa transdisciplinar: bases epistemológicas para a coconstrução do conhecimento do projeto INCT-Odisseia, estudo de caso do Baixo São Francisco. Texto para Discussão (Série Working Papers №. 5), Brasília, 2020. Available in: http://inct-odisseia.i3gs.org/wp-content/ uploads/2020/10/Working-Paper-1.pdf. Acessed: 20 Feb 2021

LISBOA, T. K.; LUSA, M. G. Desenvolvimento sustentável com perspectiva de gênero - Brasil, México e Cuba: mulheres protagonistas no meio rural. Revista Estudos Feministas, v. 18, n. 3, p. 871-887, 2010.

LITRE, G. Scientific Uncertainty and Policy Making: how can communications contribute to a better marriage in the global change arena? In: BRAIMOH, A. K.; HUANG, H. Q. (Org.). Vulnerability of Land Systems in Asia. Chichester, West Sussex, UK; Hoboken, NJ: Wiley Blackwell. p. 311-319, 2015.

LITRE, G.; CURI, M. A Força da Mulher no Campo: protagonismo feminino e sustentabilidade rural. Brasília: IABS, 2018.

MELO, H. P.; CASTILHO, M. Trabalho reprodutivo no Brasil: quem faz? R. Econ. contemp., Rio de Janeiro, v. 13, n. 1, p. 135-158, jan./abr. 2009.

MOLNÁR, Z. et al. Knowledge co-production with traditional herders on cattle grazing behaviour for better management of species-rich grasslands. Journal of Applied Ecology, v. 57, n. 9, p. 1677-1687, sep. 2020. DOI: $10.1111 / 1365-2664.13664$

MORAES, M. História Oral, Memória e Geração: narrativas de mulheres rurais do município de Lagoão-RS (19422019). Dissertação (Mestrado em História) - Universidade Federal do Rio Grande do Sul, Programa de PósGraduação em História, Porto Alegre, 2020.

NARVAZ, M. G.; KOLLER, S. H. Famílias e patriarcado: da prescrição normativa à subversão criativa. Psicol. Soc., v, 18, n. 1, Abr. 2006. 
ORGANIZAÇÃO DAS NAÇÕES UNIDAS. Nações Unidas Brasil. ONU Mulheres. FAO lança quarta edição da campanha "Mulheres Rurais, Mulheres com Direitos". Publicado em 08/03/2019. Available in: http://www.fao.org/brasil/ noticias/detail-events/pt/c/1184620/. Acessed: 20 Feb 2021

$\mathrm{POHL}, \mathrm{C}$. et al. Researchers' roles in knowledge co-production: experience from sustainability research in Kenya, Switzerland, Bolivia and Nepal. Science and Public Policy, v, 37, n. 4, p. 267-281, 2010. DOI: https://doi. org/10.3152/030234210X496628

RODRIGUES, H. B. C. Cura, culpa e imaginário radical em Cornelius Castoriadis: percursos de um sociobárbaro. Psicol., USP, São Paulo, v. 9, n. 2. 1998.

SAITO, C. H.; NOGUEIRA, D. Gênero: uma abordagem necessária para a gestão das águas. Sustentabilidade em Debate, Brasília, v. 8, n. 3, p. 13-15, dez. 2017.

SALES, C. M. V. Mulheres Rurais: tecendo novas relações e reconhecendo direitos. Estudos Feministas, Florianópolis, v. 15, n. 2, p. 437-332, mai/ago. 2007.

SANTOS, R.; REZENDE, T. Z.; MARTINS, M. B. Plano Estadual dos Direitos da Mulher: 2018-2021. Curitiba, PR: Secretaria de Estado da Família e Desenvolvimento Social (Seds), 2018.

SARDENBERG, C. M. B. Conceituando "Empoderamento" na Perspectiva Feminista. In: SEMINÁRIO INTERNACIONAL: TRILHAS DO EMPODERAMENTO DE MULHERES - PROJETO TEMPO, 1., 2006, Anais [...] Salvador, BA: NEIM/UFBA, 2006.

SCOTT, J. Gênero: uma categoria útil de análise histórica. Trad. Christine Rufino Dabat e Maria Betânia Ávila. Recife: SOS Corpo, 1991.

SILVA, M. R. et al. Mulheres do Sertão: avaliação dos impactos do Pronaf Mulher para a autonomia feminina do semiárido cearense. In: CHACON, S. S.; NASCIMENTO, V. S.; LIMA JÚNIOR, J. F. (Org.). Participação, Protagonismo Feminino e Convivência com o Semiárido. Rio de Janeiro: Garamond, IABS, 2015. p. 11-34, 2015.

SOARES, D. Vulnerabilidad y género: un acercamiento a los riesgos de desastres desde el sur de México. Sustentabilidade em Debate, Brasília, v. 8, n. 3, p. 51-63, 2017.

SPANEVELLO, R. M. et al. Contribuições do acesso ao crédito rural: uma análise entre mulheres no norte do Rio Grande do Sul. Revista Grifos, v. 30, p. 212-235, 2021.

SPANEVELLO, R. M. et al. Perspectivas em relação ao destino do patrimônio entre agricultores familiares sem sucessores In: Agronomia: jornadas científicas. Guarujá, SP: Editora Científica Digital, 2020, v. 2, p. 149-157.

SPANEVELLO, R. M.; MATTE, A.; BOSCARDIN, M. Crédito rural na perspectiva das mulheres trabalhadoras rurais da agricultura familiar: uma análise do Programa Nacional de Fortalecimento da Agricultura Familiar (Pronaf). Polis (Santiago. en línea), v. 44, p. 1-15. 2016.

SPECHT, A. A. Autonomia crítica das mulheres rurais: a casa pode cair, elas querem voar. Dissertação (Mestrado em Meio Ambiente e Desenvolvimento Rural) - Universidade de Brasília, Programa de Pós-Graduação em Meio Ambiente e Desenvolvimento Rural, Brasília, 2019.

VIVEROS VIGOYA, M. As cores da masculinidade: experiências interseccionais e práticas de poder na nossa América. Tradutor Allyson de Andrade Perez. Rio de Janeiro: Papéis Selvagens, 2018.

WILLIAMS, P. O empoderamento feminino e as mulheres do programa Bolsa Família. Revista Três Pontos, Belo Horizonte, v. 11, n. 1, jul. 2014. 